\title{
Tenascin-C expression in normal, inflamed, and scarred human corneas
}

\author{
H Maseruka, R E Bonshek, A B Tullo
}

\begin{abstract}
Aims/background-In adult tissues the expression of tenascin-cytotactin (TN-C), an extracellular matrix glycoprotein, is limited to tumours and regions of continuous renewal. It is also transiently expressed in cutaneous and corneal wound healing. There are limited data regarding its expression in inflammation and scarring of the adult human cornea. In this study, TN-C expression patterns in normal, inflamed, and scarred human corneas have been examined.

Methods-Penetrating keratoplasty specimens were selected from cases of herpes simplex keratitis, herpes zoster ophthalmicus, rheumatoid arthritis ulceration, bacterial keratitis, rosacea keratitis, interstitial keratitis, and previous surgery so as to encompass varying degrees of active and chronic inflammation and scarring. TN-C in these and in normal corneas was immunodetected using TN2, a monoclonal antibody to human TN-C.

Results-There was no TN2 immunopositivity in normal corneas except at the corneoscleral interface. In pathological corneas, TN2 immunopositivity was localised in and around regions of active inflammation, fibrosis, and neovascularisation. TN2 positivity was less in acute inflammation than in active chronic inflammation. Mature, avascular scar tissue and epithelial downgrowth were TN2 negative.
\end{abstract}

Conclusion-These results indicate that in the adult human cornea, TN-C expression is induced in regions of inflammation, fibrosis, and neovascularisation, but that expression is absent in mature, avascular scar tissue. This suggests a role for this glycoprotein in inflammation, healing, and extracellular matrix reorganisation of the cornea.

(Br F Ophthalmol 1997;81:677-682)

Tenascin is a large extracellular matrix glycoprotein $(\sim 190-320 \mathrm{kD})^{1}$ which has been described variously as cytotactin, ${ }^{2}$ glioma- myotendinous associated extracellular matrix (GMEM) protein, ${ }^{3}$ myotendinous antigen, ${ }^{4}$ hexabranchion, ${ }^{5}$ and J1-200/220. ${ }^{6}$ Currently, this glycoprotein is referred to as tenascincytotactin (TN-C). ${ }^{7}$

Several in vitro studies have shown that TN-C mediates a number of cellular activities. For example, it stimulates ${ }^{89}$ and inhibits ${ }^{9}{ }^{10}$ the proliferation of cells. It also interacts with fibronectin ( $\mathrm{FN})$, and supports adhesion of a variety of cell types including fibroblasts, glia, neurons, and endothelial cells. ${ }^{11-13}$ Paradoxically, antiadhesive properties have also been described, ${ }^{12}{ }^{13}$ providing evidence for multifunctionality of this glycoprotein.

TN-C shows a time and tissue specific expression in the developing embryo. It is, for example, present at the epithelial mesenchyme interfaces of skin, oral mucosa, lung, genitourinary tract, gastrointestinal tract, kidney, breast, and in the developing brain and cornea. ${ }^{2} 81415$ In adult tissues TN-C expression is limited to tumours, regions of continuous renewal, and wound healing (reviewed by Sakakura and Kusano $^{16}$ ).

Although TN-C is expressed in developing human fetal cornea, ${ }^{15}$ in normal adult human cornea very low expression has been demonstrated in corneal epithelial cells only, ${ }^{17}$ with a greater degree of expression at the limbal region. ${ }^{17}{ }^{18}$ In rabbits, however, TN-C has been detected in the entire normal corneal epithelium, but it is absent in the stroma. ${ }^{19-21}$ As seen in cutaneous wound healing, ${ }^{22}{ }^{23} \mathrm{TN}-\mathrm{C}$ is transiently expressed in corneal wound healing. ${ }^{17}$ 19-21 However, to date there are limited data regarding the expression of TN-C in both normal and pathological adult human corneas. This, together with a body of evidence supporting a role for this glycoprotein in influencing several cellular activities, ${ }^{268-1315}$ prompted us to examine $\mathrm{TN}-\mathrm{C}$ expression in inflamed, vascularised, and scarred human corneas. Comparison of patterns of TN-C localisation in pathological and normal corneas was aimed at determining whether a relation exists between the progression of events in inflammation, healing, and scarring, and $\mathrm{TN}-\mathrm{C}$ expression in the human cornea. 
Table 1 Source of reagents and antibodies employed

\begin{tabular}{|c|c|}
\hline Reagents/antibodies & Source \\
\hline $\begin{array}{l}\text { Mouse anti-human } \\
\text { tenascin-C (clone TN2, } \\
\text { IgG1, kappa) }\end{array}$ & Dako, UK \\
\hline $\begin{array}{l}\text { Mouse anti-human desmin } \\
\text { (clone D33, IgG1, kappa) }\end{array}$ & Dako, UK \\
\hline $\begin{array}{l}\text { Rabbit anti-mouse IgG } \\
\text { (RAM) }\end{array}$ & Dako, UK \\
\hline $\begin{array}{l}\text { Avidin-biotin/horseradish } \\
\text { peroxidase complex } \\
\text { (ABC/HRP) }\end{array}$ & Dako, UK \\
\hline $\begin{array}{l}\text { Industrial methylated spirit } \\
\text { (IMS) }\end{array}$ & Genta Medical, UK \\
\hline $\begin{array}{l}\text { 3-Aminopropyltriethoxysilane } \\
\text { (APES) }\end{array}$ & $\begin{array}{l}\text { Sigma Chemical Company, } \\
\text { USA }\end{array}$ \\
\hline Trypsin tablets & $\begin{array}{l}\text { Sigma Chemical Company, } \\
\text { USA }\end{array}$ \\
\hline Normal rabbit serum (NRS) & $\begin{array}{l}\text { Sigma Chemical Company, } \\
\text { USA }\end{array}$ \\
\hline Hydrogen peroxide $\left(\mathrm{H}_{2} \mathrm{O}_{2}\right)$ & BDH Laboratory Supplies, UK \\
\hline
\end{tabular}

\section{Materials and methods}

Thirty five corneal specimens obtained from patients aged from 3 to 97 years, who had undergone penetrating keratoplasty, were selected to encompass varying degrees of acute and chronic inflammation, and scarring. These included the following cases-bacterial keratitis (three); herpes simplex keratitis (HSK) (10); rosacea keratitis (three); herpes zoster ophthalmicus (HZO) (five); interstitial keratitis (IK) (seven); rheumatoid arthritis (RA) ulceration (five); and previous surgery (two). Ten globes enucleated for choroidal melanoma but without anterior segment pathology provided normal corneas. All tissues were fixed in $10 \%(\mathrm{v} / \mathrm{v})$ phosphate buffered formalin, $\mathrm{pH}$ 7.4 , before being dehydrated and embedded in paraffin wax.

Reagents and antibodies employed in the study are shown in Table 1. A mouse anti-human TN-C (clone TN2, isotype IgG1, kappa) obtained from Dako, UK, was employed in this study. TN2 has been employed in a number of studies investigating tissue distribution of TN-C. ${ }^{18}{ }^{24}$

Microtome sections (6 $\mu \mathrm{m})$, mounted on 3-aminopropyl-triethoxy silane (APES) coated slides, were dewaxed in xylene and rehydrated in graded $(99 \%-70 \%(\mathrm{v} / \mathrm{v}))$ industrial methyl-

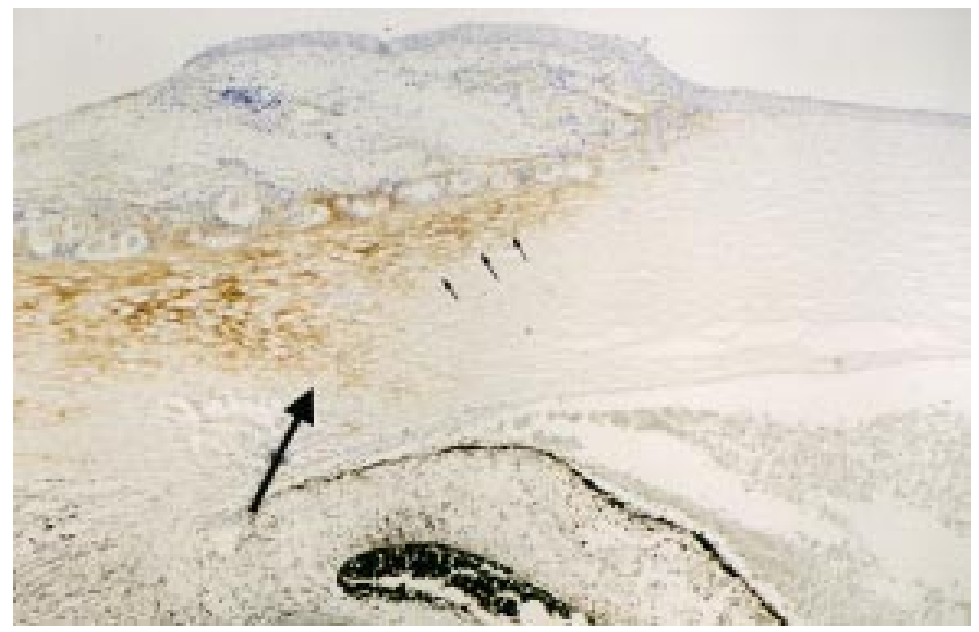

Figure 1 Normal cornea and corneoscleral interface. There is TN2 immunopositivity of the sclera (small arrows) including the scleral spur (large arrow). Corneal tissue is TN2 immunonegative $(\times 18)$. ated spirit (IMS). Endogenous peroxidase activity was quenched by a 30 minute incubation with $1 \%(\mathrm{v} / \mathrm{v})$ hydrogen peroxide $\left(\mathrm{H}_{2} \mathrm{O}_{2}\right)$, and antigenic sites unmasked by incubation with $1 \mathrm{mg} / \mathrm{ml}$ trypsin in $4 \mathrm{mM} \mathrm{CaCl}_{2}$ and 200 $\mathrm{mM}$ TRIS, $\mathrm{pH} 7.6$ (10 minutes, $37^{\circ} \mathrm{C}$ ). A solution of $20 \%(\mathrm{v} / \mathrm{v})$ normal rabbit serum (NRS) was applied to sections (15 minutes, $25^{\circ} \mathrm{C}$ ) to block non-specific binding sites. The NRS was then tipped off and sections incubated overnight $\left(4^{\circ} \mathrm{C}\right.$ ) with a $1: 25$ (v:v) TN2. Bound TN2 was detected by applying 1:100 (v:v) biotinylated rabbit anti-mouse immunoglobulins $\left(30\right.$ minutes, $25^{\circ} \mathrm{C}$ ). This was then visualised by incubating sections ( 30 minutes, $25^{\circ} \mathrm{C}$ ) with a solution of avidin-biotin horseradish peroxidase complex (ABC/HRP) and reacting with a 3,3'diaminobenzidine (DAB) tetrachloride $/ \mathrm{H}_{2} \mathrm{O}_{2}$ substrate. Sections were counterstained with Harris's haematoxylin, dehydrated in graded $(70 \%-99 \%(\mathrm{v} / \mathrm{v}))$ IMS and cleared in xylene before mounting coverslips with xylene anti-mouse IgG (XAM). Sections were viewed under a routine light microscope.

Between incubation steps, sections were dip immersion washed $(2 \times 3$ minutes $)$ in $0.05 \mathrm{M}$ TRIS buffered saline, $\mathrm{pH} 7.6$, to eliminate excess non-bound antibody or reagent. Negative controls included substitution of TN2 with an irrelevant antibody (mouse anti-human desmin, clone D33, isotype IgG1, kappa), and with $25 \%$ (v/v) NRS. No immunoreaction was observed in negative controls. Skin from a case of chronic dermatitis and sclera provided TN2 positive immunoreaction controls.

\section{Results}

TN2 immunoreaction was negative in all the normal corneas except at the corneoscleral interface (Fig 1), where sclera was positive. Generally, in all the TN2 positive corneas, stromal staining was seen mostly in an extracellular location. In cases of bacterial keratitis, TN2 was strongly positive in corneal stroma around the periphery of areas of acute inflammation and areas of active ulceration (Figs 2 and 3 ). In areas away from the main focus of inflammatory activity and where there was separation of epithelium from stroma, there was increased subepithelial staining (Fig 2). At higher magnification (Fig 3) focal TN2 staining was seen in occasional keratocytes/ fibroblasts in acutely inflamed tissue. It was apparent that much of the intense stromal TN2 immunoreaction around the inflamed areas was associated with chronic inflammatory cell infiltrate, although the infiltrating cells were themselves negative. An intermittent line of staining was also seen at the junction between Descemet's membrane and the posterior stroma (Fig 3).

Cases of HSK, rosacea keratitis, and HZO showed heterogeneity of stromal staining for TN2. However, in all cases there was stromal TN2 immunoreactivity associated with active chronic inflammation (Fig 4). As in the chronic inflammation around the area of acute inflammatory activity shown in Figures 2 and 3, the inflammatory cells were TN2 negative, and there was focal positivity of the stroma/ 


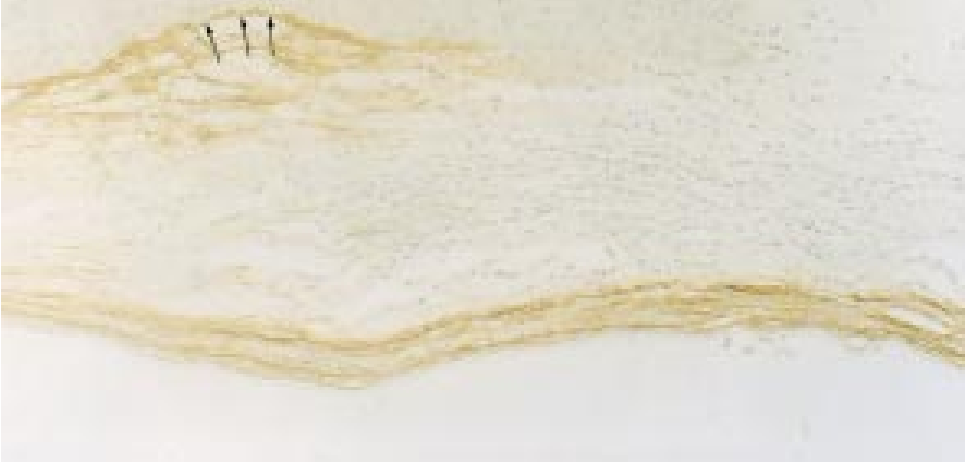

Figure 2 Bacterial keratitis, with ulcer and stromal abscess. Strong TN2 immunopositivity in and around the edges of the acutely inflamed tissue. The ulcer, epithelium, and stroma immediately adjacent are negative. There is also subepithelial TN2 immunopositivity in an area of epithelial lifting from oedematous stroma (small arrows) ( $\times 38)$.

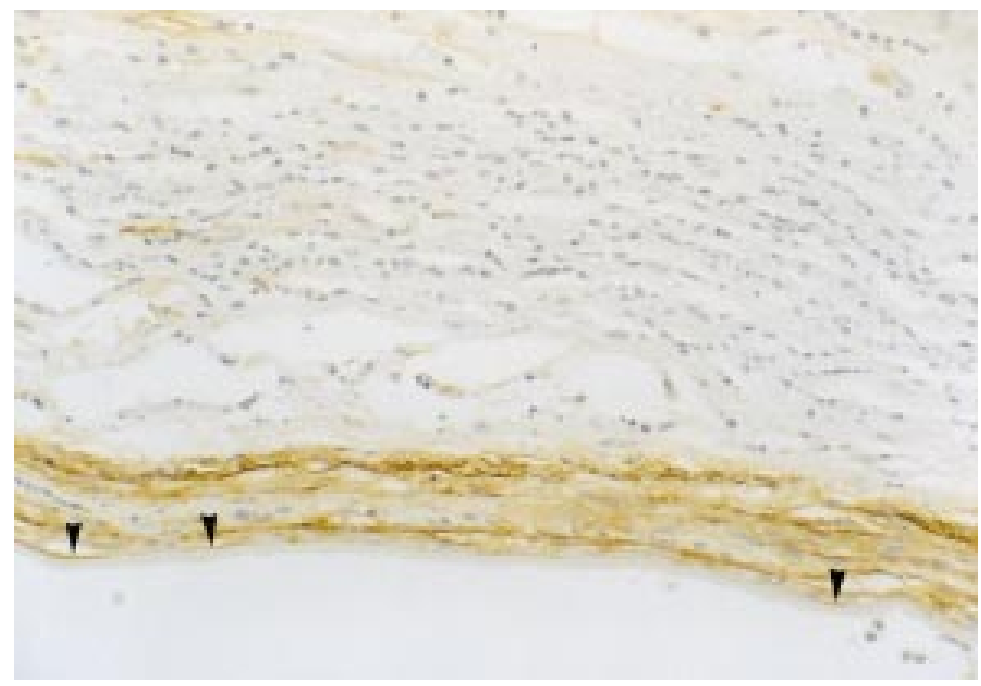

Figure 3 Bacterial keratitis, higher magnification. Occasional TN2 positive keratocytes are seen in the acutely inflamed area. However, the strongest TN2 immunoreaction is in the posterior stroma where there is a chronic inflammatory cell infiltrate, rather than in the acutely inflamed tissue of mid stroma. The chronic inflammatory cells are negative, but the stromal tissue is positive. Note that Descemet's membrane is negative, but there is a band of TN2 immunopositivity at the interface between posterior stroma and Descemet's membrane (arrowheads). Endothelium has been lost from this cornea $(\times 185)$.

Descemet's membrane interface. There was no difference in the patterns of TN2 staining seen with respect to any of these three aetiologies.

IK corneas were negative except for occasional vessels where there was weak TN2 immunopositivity in vascular endothelial cells (not shown). In the majority of RA corneas there were few infiltrating inflammatory cells and there was focal faint TN2 immunostaining associated with these cells. One RA cornea had perforated and contained a strip of intact epithelium which spanned the perforation. This cornea showed strong TN2 positivity in stroma adjacent to the perforation, especially in early subepithelial fibrous scar tissue, and in basement membrane-like material which lay beneath epithelium spanning the defect and which was devoid of substratum (Fig 5).
In corneas with previous surgery there was TN2 immunostaining in regions of active scar tissue, associated with some chronic inflammatory cells, where stromal and lymphocyte cytoplasmic membrane staining was seen, and some vascular endothelial cells, where there was intracytoplasmic staining (Fig 6). However, where scars were uncomplicated, no TN2 immunopositivity was seen (Fig 7). In one case with an epithelial downgrowth, but with no scarring, TN2 immunoreaction was negative (Fig 8). In some pathological corneas, without any specificity for any disease type, occasional epithelial cells showed granular epithelial cytoplasmic TN2 immunostaining (Figs 6 and 7).

\section{Discussion}

Tenascin was not detected in normal human corneal structures except at the corneoscleral interface. This observation is consistent with the findings of Uusitalo ${ }^{18}$ who employed the same antibody (clone $\mathrm{TN} 2$ ) which recognises all TN-C variants. However, Tervo et al, have reported immunodetectable $\mathrm{TN}-\mathrm{C}$ in normal human corneal epithelium, but in agreement with our observation, these authors noted a greater localisation of TN-C at the corneoscleral margin. ${ }^{17}$ It is unfortunate that their description of corneal epithelial staining is found only in the abstract of their paper and is not mentioned in either the results or discussion, nor do the photomicrographs illustrate this corneal epithelial staining. These authors employed a different monoclonal antibody (100EB2), which recognises an epitope within a conserved FN type III repeat region of the TN-C molecule. ${ }^{25}$ Thus differences in epitope specificity may be involved, or there may be differences due to masking of epitopes because of fixation, as they used an immunofluorescence method with fresh tissue. We have recently used BC4, a monoclonal antibody described by Siri et al, ${ }^{125}$ with results identical to those of TN2 (unpublished observations). Species differences in TN-C expression exist, as $\mathrm{TN}-\mathrm{C}$ has also been immunodetected in the entire epithelium of normal rabbit corneas. ${ }^{19-21}$ In pathological corneas and those with previous surgery, localisation of TN-C was observed around active ulcers and foci of acute inflammation, within chronically inflamed tissue and granulation tissue, and in vascularised regions. $\mathrm{Old} /$ mature avascular scar tissue was $\mathrm{TN}-\mathrm{C}$ negative.

The absence of TN-C in normal corneas, its expression in inflammation and neovascularisation, and its disappearance in quiescent fibrosis, as seen in mature scar tissue, mirrors the situation described in cutaneous and experimental corneal wound healing. ${ }^{17}{ }^{19-23}$ In cryptogenic fibrosing alveolitis (CFA), TN-C expression has also been reported in areas of inflammation and active disease but not in end stage scarred tissue. ${ }^{24}$ Of interest, the heterogeneity of TN-C expression which is a feature seen in our HSK, rosacea, and HZO corneas was also observed in CFA. ${ }^{24}$ Moreover, there was no difference in the patterns of staining which could be ascribed to a viral aetiology. 


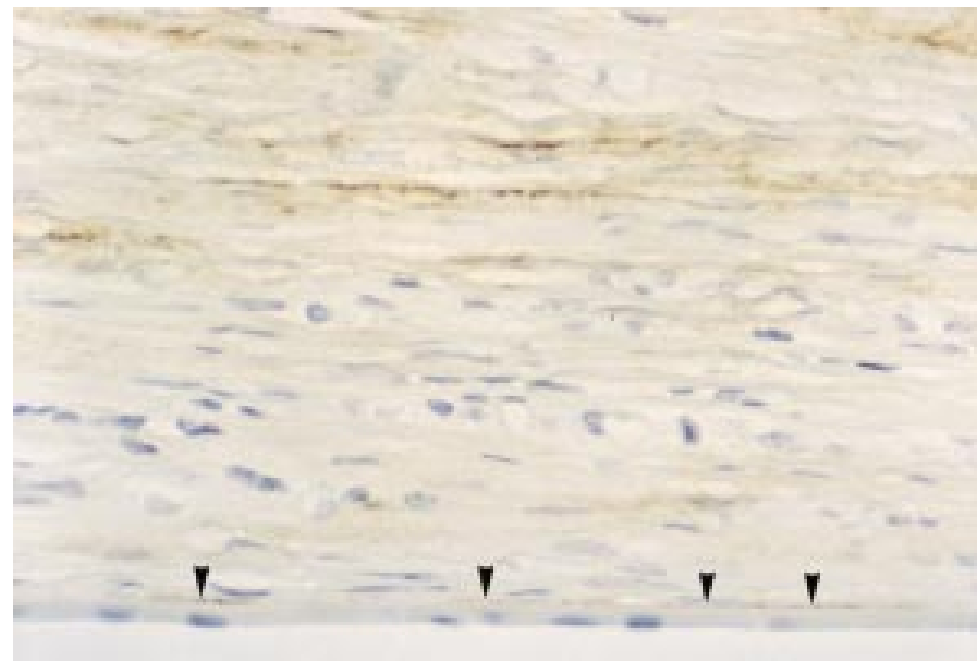

Figure 4 Herpes simplex keratitis cornea. There is stromal TN2 immunopositivity associated with chronic inflammation in the posterior stroma. Inflammatory cells are negative. Note that, as in Figure 3, there is also focal positivity at the interface between posterior stroma and Descement's membrane (arrowheads). Endothelium is intact $(\times 370)$.

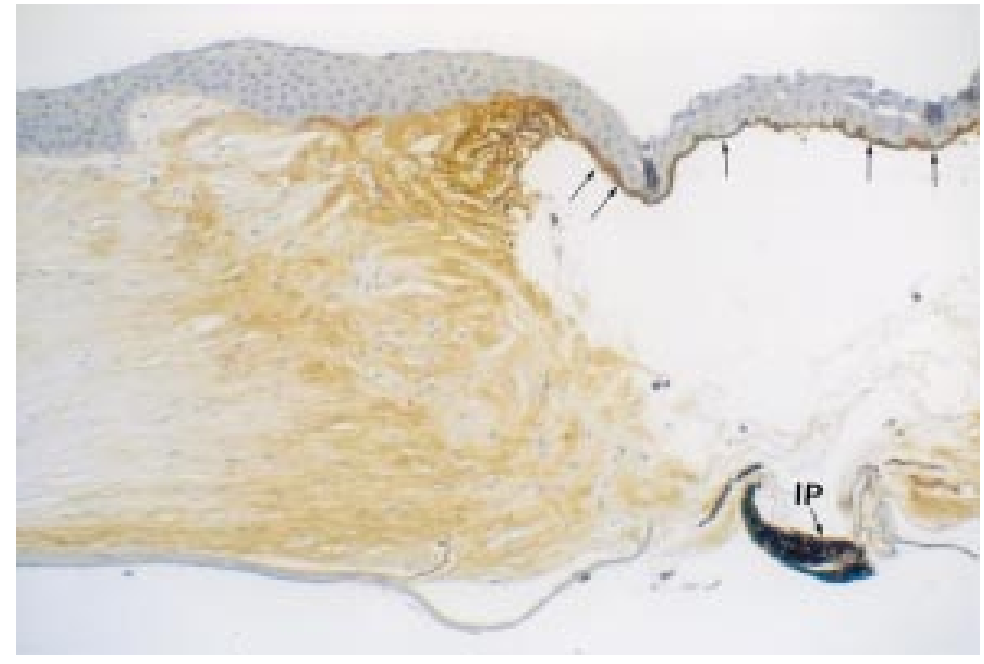

Figure 5 Rheumatoid perforation with an area of epithelium bridging a stromal defect. There is diffuse, extracellular, stromal TN2 immunopositivity around the defect. The small amount of subepithelial tissue remaining beneath the undermined epithelium is also strongly positive (small arrows). Iris pigment (IP) is present as discrete deposits in the posterior stroma below and adjacent to the perforation. Very few inflammatory cells are present $(\times 38)$.

Morphologically, there are no histological features which allow an aetiological distinction between chronic HSK, rosacea, or HZO; thus, the TN-C immunoreactivity observed presumably reflects factors associated with the chronic inflammatory response, fibrosis, and neovascularisation common to these conditions. Data from in vitro and tissue distribution studies have implicated TN-C in signalling cells to alter the expression of genes involved in extracellular matrix (ECM) synthesis and remodelling processes as seen in wound healing. ${ }^{23}$ TN-C is produced by cultured fibroblasts, ${ }^{23}$ and an upregulation of synthesis of proteolytic enzymes, such as collagenase, stromelysin, and the $92 \mathrm{kDa}$ gelatinase is commonly observed in fibroblasts plated on a mixed substrate of fibronectin and $\mathrm{TN}-\mathrm{C} .{ }^{26} \mathrm{TN}-\mathrm{C}$ expressed around ulcers and acute inflammation, and in chronically inflamed and fibroblastic areas of these corneas, possibly modulates ECM re-

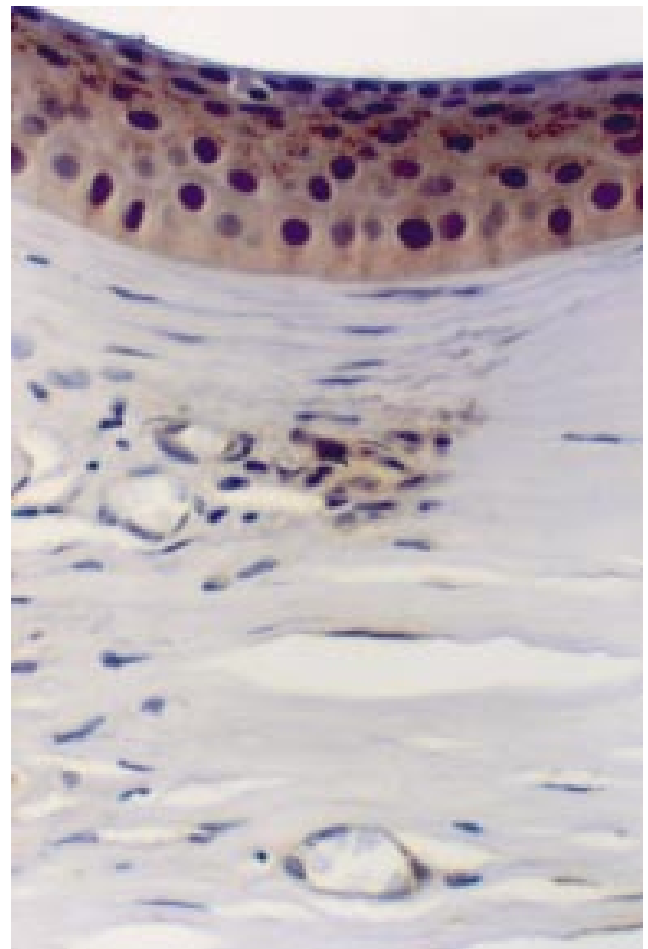

Figure 6 Previous surgery. There is patchy chronic inflammation and vascularisation. TN2 immunopositivity is present in the stroma where there is an aggregate of chronic inflammatory cells. Here, occasional lymphocytes have cytoplasmic membrane staining. Elsewhere, there is cytoplasmic labelling of some vascular endothelial cells. There is also granular cytoplasmic staining of epithelial cells overlying this area $(\times 450$, oil immersion $)$.

modelling during the healing and repair processes which are a component of the chronic inflammatory response. This is supported by the absence of TN-C in quiescent, burnt out scars.

On the other hand, it has been suggested that $\mathrm{TN}-\mathrm{C}$ acts as an immunomodulator by altering the adhesion of monocytes and $\mathrm{B}$ and T lymphocytes. ${ }^{27}{ }^{28}$ Stromal TN2 positivity was strongest in areas of chronic inflammatory activity and the observation of occasional lymphocyte cytoplasmic membrane $\mathrm{TN} 2$ positivity in areas of stromal TN2 positivity in post surgical scarring and vascularisation (Fig 6) would be consistent with TN-C bound to cell surface receptors. Certainly, these cells would be recruited in the transition from the acute to the chronic phase of the inflammatory response.

The focal TN-C expression seen in vascular endothelial cells and in surrounding stroma in some of the HSK, rosacea keratitis, and IK corneas, and in some active scar tissue may support suggestions that $\mathrm{TN}-\mathrm{C}$ is expressed in activated vascular endothelial cells. ${ }^{29} \mathrm{TN}-\mathrm{C}$ expression has been reported in tissue surrounding hyperplastic capillaries around tumours. ${ }^{29}{ }^{30}$ There is also evidence from in vitro studies that capillary endothelial cell morphology and behaviour are influenced by $\mathrm{TN}-\mathrm{C}$ present in underlying medium via an integrin dependent process. ${ }^{31}$ Antibodies to TN-C have also been shown to inhibit angiogenesis in vitro. ${ }^{32}$ Our observed TN2 positivity around the periphery of areas of 


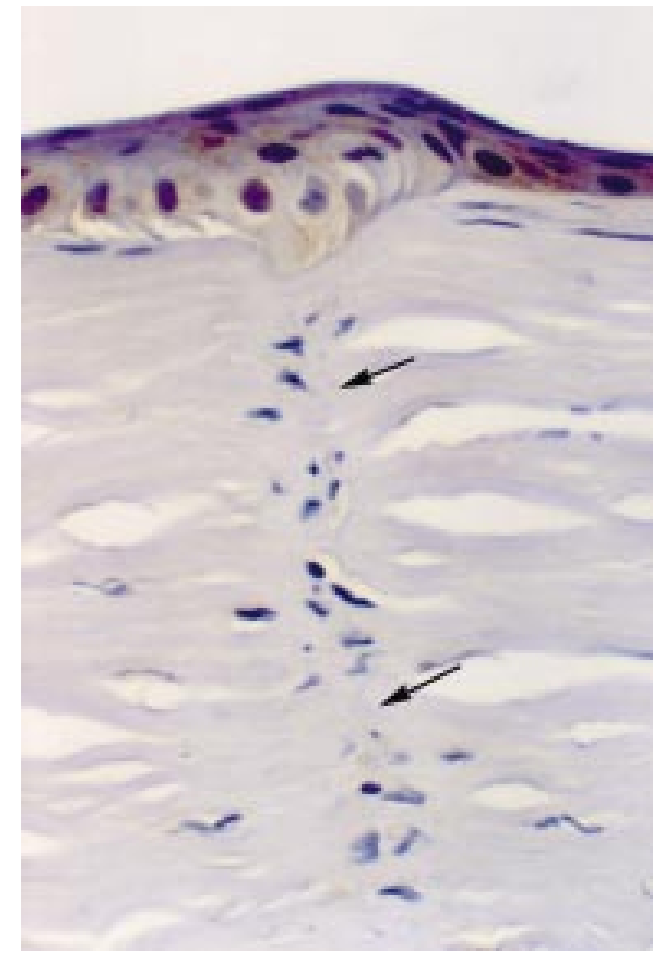

Figure 7 Healed 2 year old surgical incision. There is minimal fibroblastic reaction and no vascularisation or inflammation. TN2 immunoreaction is negative in the mature scar tissue (arrows). There is faint granular TN2 immunopositivity in the epithelium above the scar $(\times 450$, oil immersion).

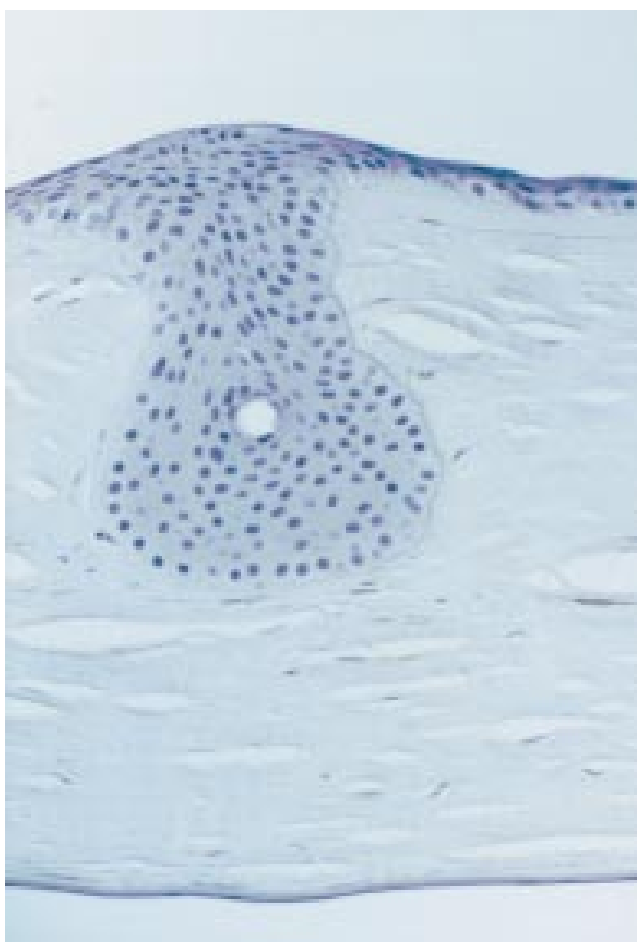

Figure 8 Epithelial downgrowth that fills a previous relaxing incision. TN2 immunoreaction is negative in both stroma and epithelium $(\times 180$, differential interference contrast (DIC)).

acute inflammation and ulceration may, therefore, be consistent with a role for TN-C in promoting angiogenesis and vascular proliferation.

The observed strong subepithelial TN2 staining in the rheumatoid arthritis (RA) cornea where the epithelium is detached (Fig 2 ) is of considerable interest. In this situation there appears to be increased TN-C expression by the epithelial cells, with immunolocalisation in the extracellular basement membrane $(\mathrm{EBM})$ zone, which is thickened. A similar appearance is seen in a case of bacterial keratitis (Fig 2) where the epithelium has partially lifted from oedematous stroma. These findings, also reported in dermo-epidermal separation of human skin, ${ }^{33}$ indicate that $\mathrm{TN}-\mathrm{C}$ expression is induced in situations where there is loss of attachment of epithelium to substratum. This may suggest that the epithelium is the source of TN-C in these cases. The granular cytoplasmic TN2 staining in the epithelium of several of the pathological corneas could also be interpreted in this way and may be consistent with the observations of Tervo et al. ${ }^{17}$ $\mathrm{TN}-\mathrm{C}$ is known to bind to proteoglycans which are basement membrane components ${ }^{13}$; thus, the TN2 positivity seen in the EBM zone and at the interface between Descemet's membrane and the posterior stoma may reflect this property.

Our findings, together with the body of data regarding the structure of $\mathrm{TN}-\mathrm{C}$ and its expression in a variety of tissues during development, in wound healing events, and in pathological states, indicate a functional role for this molecule. The development of the 'tenascin gene knockout mouse', which develops normally despite an absent functional tenascin gene, ${ }^{34}$ presents a paradox, appearing to contradict this evidence. However, a number of gene deletions in mice have resulted in surprisingly mild or undetectable phenotypic alterations ${ }^{35-40}$ and, even in cases where a mutant mouse mimics a human disease, the mutant mouse does not always provide an exact model for the aetiology and pathogenetic mechanisms (reviewed by Smithies ${ }^{41}$ ). Furthermore, other members of the tenascin family (reviewed by Chiquet-Ehrismann et al ${ }^{7}$ ) might compensate for the loss of one component.

In conclusion, the patterns of TN-C expression observed in this study indicate that in the human adult cornea, TN-C is induced in inflammatory states, especially where there appears to be fibroblastic activity, and that it is not expressed in mature avascular scar tissue. This pattern of expression suggests an important role for this glycoprotein in inflammation, healing, and in the extracellular matrix remodelling of the human cornea.

This study was supported by a North West Regional Health Authority grant and Manchester Royal Eye Hospital Endowments.

1 Siri A, Carnemolla B, Saginati M, Leprini A, Casari G, Baralle F, et al. Human tenascin: primary structure, premRNA splicing patterns and localisation of the epitopes recognised by two monoclonal antibodies. Nucleic Acids Res 1991;19:525-31.

2 Grumet M, Hoffman S, Crossin KL, Eldelman GM. Cytotactin, an extracellular matrix protein of neural and Proc Natl Acad Sci 1985;82:8075-9.

3 Bourdon MA, Wikstrand CJ, Furthmaryr H, Matthews TJ, Bigner DD. Human glioma-mesenchymal extracellular matrix antigen defined by monoclonal antibody. Cancer Res matrix antigen defin

4 Chiquet M, Fambrough DM. Chick myotendinous antigen Chiquet M, Fambrough DM. Chick myotendinous antigen
II. A novel extracellular matrix glycoprotein complex con- 
sisting of large disulphide-linked subunits. $\mathcal{F}$ Cell Biol 1984; 98:1937-46.

Erickson HP, Inglesias JL. A six-armed oligomer isolated from cell surface fibronectin preparations. Nature 1984; 311:267-9.

6 Kruse J, Keilhauer G, Faissner A, Timpl R, Schachner M. The J1 glycoprotein-a novel nervous system cell adhesion molecule of the L2/HNK-1 family. Nature 1985;316:146-8.

7 Chiquet-Ehrismann R, Hagios C, Matsumoto K. The tenascin gene family. Perspect Develop Neurobiol 1994;2:3-7.

8 Chiquet-Ehrismann R, Mackie J, Pearson C, Sakakura T. Tenascin: an extracellular matrix protein involved in tissue interactions during foetal development and oncogenesis. Cell 1986;47:131-9.

9 End P, Panayotou G, Entwistle A, Waterfield MD, Chiquet M. Tenascin: a modulator of cell growth. Eur $\mathcal{F}$ Biochem 1992;209:1041-51.

10 Crossin KL. Cytotactin binding: inhibition of stimulated proliferation and intracellular alkalinisation in fibroblasts. proliferation and intracellular alkalin.

11 Joshi P, Chung C-Y, Aukhil I, Erickson HP. Endothelial cells adhere to the RGD domain and the fibrinogen-like termiadhere to the RGD domain and the fibrinogen-like

12 Spring J, Beck K, Chiquet-Eherismann R. Two contrary functions of tenascin: dissection of the active sites by recombinant tenascin fragments. Cell 1989;59:325-34

13 Chiquet-Eherismann R. Anti-adhesive molecules of the extracellular matrix. Curr Opin Cell Biol Chem 1991;3:8004.

14 Erickson HP, Bourdon MA. Tenascin: an extracellular matrix protein prominent in specialised embryonic tissues and tumours. Annu Rev Cell Biol 1989;5:71-92.

15 Kaplony A, Zimmermann DR, Fischer RW, Imhoff BA, Odermatt BF, Winterhalter KH, et al. Tenascin $M_{\mathrm{r}} 220,000$ isoform expression correlates with corneal migration. Development 1991;112:605-14.

16 Sakakura T, Kusano I. Tenascin in tissue perturbation. Acta Pathol fpn 1991;41:247-58.

17 Tervo T, van Setten GB, Lehto I, Tervo K, Tarkkanen A, Virtanen I. Immuno-histochemical demonstration of tenascin in the normal human limbus with special reference to trabeculectomy. Ophthalmic Res 1990;22:128-33.

18 Uusitalo M. Immunohistochemical localisation of chondroitin sulphate proteoglycan and tenascin in the human eye compared with HNK-1 epitope. Graefes Arch Clin Exp Ophthalmol 1994;232:657-65.

19 Latvala T, Tervo K, Mustonen R, Tervo T. Expression of cellular fibronectin and tenascin in the rabbit cornea after excimer laser photorefractive keratectomy: a 12 month study. Br $\mathcal{F}$ Ophthalmol 1995;79:65-9.

20 Tervo K, van Setten GB, Beuerman RW, Virtanen I, Tarkkanen A, Tervo T. Expression of tenascin and cellula fibronectin in the rabbit cornea after anterior keratectomy. Immunohistochemical study of wound healing dynamics. Invest Ophthalmol Vis Sci 1991;32:2912-8

21 Van Setten GB, Koch JW, Tervo K, Lang GK, Tervo T, Naumann GO, et al. Expression of tenascin and fibronectin in the rabbit cornea after excimer laser surgery. Graefes Arch Clin Exp Ophthalmol 1992;230:178-83.

22 Betz P, Nerlich A, Tubell J, Penning R, Eisenmenger W. Localisation of tenascin in human skin wounds-an immuLocalisation of tenascin in human skin wounds-an im
nohistochemical study. Int f Leg Med 1993;105:325-8.

23 Mackie EJ, Halfter W, Liverani D. Induction of tenascin in healing wounds. F Cell Biol 1988;107:2757-67.
24 Wallace WAH, Howie SEM, Lamb D, Salter DM. Tenascin immunoreactivity in cryptogenic fibrosing alveolitis. $\mathcal{f}$ Pathol 1995;175:415-20.

25 Balza E, Siri A, Ponassi M, Caocci F, Linnala A, Virtanen I, et al. Production and characterization of monoclonal antibodies specific for different epitopes of human tenascin. FEBS Lett 1993;332:39-43.

26 Tremble P, Chiquet-Ehrismann R, Werb Z. The extracellular matrix ligands fibronectin and tenascin collaborate in regulating collagenase gene expression in fibroblasts. $\mathrm{Mol}$ Biol Cell 1994;5:439-53.

27 Ruegg CR, Chiquet-Ehrismann R, Alkan SS. Tenascin, an extracellular matrix protein, exerts immunomodulatory activities. Proc Natl Acad Sci 1989;86:7437-41.

28 Hemasath TJ, Marton LS, Stefansson K. Inhibition of T cell activation by the extracellular matrix protein tenascin. $\mathcal{F}$ Immunol 1994;152:4199-5207.

29 Zagzag D, Friedlander DR, Dosik J, Chikramane S, Chan W, Greco MA, et al. Tenascin-C expression by angiogenic vessels in human astrocytomas and by human brain endothelial cells in vitro. Cancer Res 1996;56:182-9.

30 Zagzag D, Friedlander DR, Miller DC, Dosik J, Cangiarella J, Kostianovsky M, et al. Tenascin expression in astrocytomas correlates with angiogenesis. Cancer Res 1995;55:907-

31 Sriramarao P, Mendler M, Bourdon MA. Endothelial cell attachment and spreading on human tenascin is mediated by $\alpha_{2} \beta_{1}$ and $\alpha_{1} \beta_{3}$ integrins. F Cell Sci 1993;105:1001-12.

32 Canfield AE, Schor AM. Evidence that tenascin and thrombospondin-1 modulate sprouting of endothelial cells. 7 Cell Sci 1995;108:797-809.

33 Schenk S, Bruckner-Tuderman L, Chiquet-Eherismann R. Dermo-epidermal separation is associated with induced tenascin expression in human skin. $\mathrm{Br} \quad \mathrm{f}$ Dermatol 1995;133:13-22.

34 Saga Y, Yagi T, Ikawa Y, Sakakura T, Aizawa S. Mice develop normally without tenascin. Genes Dev 1992;6: 1821-31.

35 Brookfield J. Can genes be truly redundant? Curr Biol 1992; 2:553-4.

36 Braun T, Rudnicki MA, Arnold H-H, Jaenisch R. Targeted inactivation of the muscle regulatory gene Myf- 5 results in abnormal rib development and perinatal death. Cell 1992; 71:369-82.

37 Joyner AL, Herrup K, Auerbach BA, Davis CA, Rossant J. Subtle cerebellar phenotype in mice homozygous for a targeted deletion of the En-2 homeobox. Science 1991;251: 1239-43.

38 Rudnicki MA, Braun T, Hinuma S, Jaenisch R. Inactivation of MyoD in mice leads to up-regulation of the myogenic HLH gene Myf- 5 and results in apparently normal muscle development. Cell 1992;71:383-90.

39 Rothe J, Lesslauer W, Lotscher H, Lang Y, Koebel P, Kontgen F, et al. Mice lacking the tumour necrosis factor receptor 1 are resistant to TNF-mediated toxicity but highly susceptible to infection by Listeria monocytogenes. Nature 1993; 364:798-802.

40 Hooper C. Genetic knockouts: surprises, lessons, dreams. fNIH Res 1992;4:34-5.

41 Smithies O. Animal models of human genetic diseases. TIG 1992;9:112-6. 